\title{
A Prairie Chicken at Old Wives Lake
}

\section{By Roger Tory Peterson}

In 1953 when James Fisher and I made our marathon journey around the perimeter of "Wild" America, we compiled a total list of 601 species in exactly 100 days. There were very few North American birds left for my British colleague to see when he attended the A.O.U. meetings in Regina this last August. However, the ncrthern plains had been the greatest omission on our lethal tour and therefc re he expressed a desire to see six or seven species which would be new to him. These were the Lark Bunting, Baird's Sparrow, Chestnut-coluared Longspur, MoCown's Longspur, Sprague's Pipit, Sharp-tailed Grouse and Pinnated Grouse. I informed him that we had a fair chance to see all but the latter bird.

It was with such a pronouncement in his ears that we started for Old Wives' Lake on Tuesclay, August 25, the opening day of the convention. While the council meetings were on, Dr. Walter Breckraridge, James Fisher and I slipped out for a few hours in the field. Dr. Breckenridge particularly wanted to document photographically an outbreak of botulism at Old Wives' Lake. We drove west from Regina to Moose Jaw and then south to Bishopric. We could see the broad lake in the distance, but our directions were vague and we floundered about on dirt roads trying to reach its margin. While still three-quarters of a mile from the east side of the lake, Dr. Breckenridge let us out of the car for a bit of birding on foot while he went down a side road to a ranch house to ask directions.

Curiously enough, a few minutes before, I had wondered about why there shouldn't be Prairie Chickens here. We agreed that it was one of the best looking bits of original prairie we had seen, unplowed and not overgrazed. But Baird's Sparrows were on our minds when we crossed the fence and walked toward a depression where several cattle were grazing. Trying to flush sparrows from a patch of very low shrubs, I jumped a cock Pinnated Grouse. It was within 100 feet of me when it flushed and close enough to see its handsome barrings. I yelled to James Fisher who was off to one side and told him to take note of the short rounded dark tail. This we both saw well.

The bird scaled over a nearby rise and went out of sight. We did not flush it again.

Although I had not expected to see a Pinnated Grouse I had not realized how good our find was until Dr. Frederick Hammerstrom informed me that there had not been a reliable record in the region in more than ten years. Curiously enough, James Fisher never did see a Sharp-tail during his week in Saskatchewan.

\section{CO-OPERATIVE BIRD MIGRATION STUDY}

For the past seven years, hundreds of cbservers throughout the continent have coeparted in a spring migration study for a selected list of species of birds, carried out under the auspices of the U.S.A. Fish and Wilclife Service. This year the Blue Jay is again participating in the study, and members of the Saciety are urged to keep migration dates and submit their records to us. Information is reguested on first seen dates, and if possible dates of peak migration and final departure. Information is wanted on the following species: Whistling Swan, Canada Goose, Mallard, Pintail, Marsh Hawk, Killdeer, Common Snipe,
Mourning Dove, Common Nighthawk, Chimney. Swift, Ruby-throated Hummingbird, Yellowshafted Flicker, Eastern Kingbird, Great Crested Flycatcher, Eastern Phoebe, Western Wood Pewee, . Barn Swallow, Purple Martin, Common Crow, House Wren, Catbird, Brown Thrasher, Wood Thrush, Eastern Bluebird (male), Eastern Bluebird (female), Red-eyed Vireo, Black-and-White Warbler, Yellow Warbler, Myrtle Warbler, Ovenbird, American Redstart, Redwinged Blackbird, Baltimore Oriole, Scarlet Tanager, Rose-breasted Grosbeak, Indigo Bunting, American Goldfinch, Slate-colored Junco, Chipping Sparrow, Whitecrowned Sparrow, White-throated Sparrow. 